\title{
Potential Drawbacks of Price-based Accounting in the Insurance Sector"
}

\author{
Andrea Beltratti ${ }^{\mathrm{a}}$, Giuseppe Corvino ${ }^{\mathrm{b}}$ \\ ${ }^{a}$ Università Bocconi, Istituto di Economia Politica, Via Gobbi 5, 20136 Milano, Italy. \\ E-mail: andrea.beltratti@unibocconi.it \\ ${ }^{\mathrm{b}}$ Università Bocconi, Viale Isonzo 25, 20135 Milano, Italy. \\ E-mail: Giuseppe.corvino@unibocconi.it
}

This paper analyzes the relevance of cost-based accounting in financial markets, focusing on the drawbacks associated with a move from cost- to price-based accounting. While the benefits of such a move are well known, much less attention has been given to the potential hidden costs. We explore such hidden costs looking at both companies and investors. From the point of view of insurance companies, we consider issues like the potential increase in earnings volatility and changes in the cost of capital. From the point of view of the final investor, we consider liquidity and expected returns, stressing the role of behavioral models. Our conclusion is that cost-based accounting is a useful addition to financial markets. It may stabilize short-run financial results and may improve the situation of investors with short horizons and loss aversion. It is certainly true that cost-based financial products are not fully transparent and leave to the asset manager large discretion in the determination of short-run returns. However, we believe that cancellation of cost-based financial products is not the right reaction to these drawbacks. Rather, we believe that regulation and monitoring is the best answer.

The Geneva Papers (2007) 32, 163-177. doi:10.1057/palgrave.gpp.2510123

Keywords: accounting; behavior; earnings volatility; cost of capital; transparency; regulation

\section{Introduction}

The convergence process between the banking industry and the insurance industry relies heavily on financial innovation. The two industries were traditionally very different in terms of financial products and in their mission regarding satisfaction of consumers' needs. Banking was mainly associated with a mismatch between assets and liabilities, with banks borrowing short maturity funds from households and providing long maturity loans to firms. Insurance was associated with covering risks by exploiting their low correlation across insured and the law of large numbers.

Nowadays, banks are increasingly involved in the business of creating and selling insurance products and insurance companies are heavily involved in managing and selling financial products. Both types of institutions target similar needs on the part of

\footnotetext{
* The paper was presented at the Conference on the Paradigms of value, organized by Montepaschi Vita and the Geneva Association, Rome, 14 October 2006.
} 
agents, for example accumulating wealth for future pensions and protecting firms from certain types of financial risk.

Certainly, many differences remain. Focusing on continental Europe, some of these differences are mainly due to the presence of different regulatory regimes and accounting conventions. Banks and insurance companies report to different regulators and also very often are subject to different accounting regimes. In particular, banks use a standard mark-to-market (MTM) accounting regime, by which the value of financial assets is computed on the basis of prevailing market prices, whereas insurance companies use a mark-to-cost (MTC) accounting, according to which assets and liabilities are, under certain circumstances, valued at historical prices.

Such differences are extremely important to the various stakeholders. Shareholders need to assess the fundamental value of financial institutions by computing the market value of future expected fundamentals, in particular estimating the value of earnings and dividends that may be produced by the company over the long run. Such estimates may be easier to carry out for a bank that is continuously valued at market prices than for an insurance company whose balance sheet is considered at historical costs. Valuation of an insurance company is already difficult given the specific nature of its business and the timing of inflows and outflows, requiring specific assumptions about reserving temporal anticipation of the profits. ${ }^{1}$

Buyers of financial products may also be heavily affected by the different valuation of the two types of financial products. Market-based products like mutual funds and derivatives have characteristics which are very different from those of cost-based products like life insurance. The value of MTM products fluctuates with the volatility of financial markets, whereas the value of cost-based products is more stable because the supplier of the product has the freedom to manage returns and absorb a portion of market volatility (with relevant consequences for the shareholders through the mean and the volatility of profits). As a consequence, cost-based financial products are usually much more stable than MTM financial products. This stability may be particularly important to some types of investors, a point that we will explore in this research.

Such differences between banks and insurance companies may disappear or at least fade out in the future due to convergence in regulation and accounting regimes. More specifically, the introduction of the International Financial Reporting Standards (IFRS) promises to deeply affect the business model of insurance companies with potentially deep impacts on their market valuation, the management of companies and the perception, on the part of buyers, about the return and risk associated with the sale of insurance products. These issues are explored in this research.

We particularly study two elements. The first has to do with the impact of IFRS on the value of the insurance companies. As there is no ground to believe that IFRS will impact the mean value of earnings and dividends, we concentrate on their volatility and we ask whether increases in the volatility of earnings and dividends may affect the value of insurance companies. This depends on the pricing model used by financial markets to allow for risk. The theory suggests that only non-diversifiable risk should matter for pricing. We therefore study whether IFRS-induced volatility may be in any

\footnotetext{
${ }^{1}$ See, for example, Booth et al. (1999).
} 
way associated with an increase in non-diversifiable risk. We then look at the available literature and note that some results suggest that idiosyncratic volatility is sometimes priced in the market. Finally, we also observe that the management of companies on the part of directors is not exogenous to the overall framework and may change as a reaction to changes induced by regulation and accounting regimes. These elements leave a wide range of possibilities about the impact of IFRS on the valuation of insurance companies.

The second element that we study is the impact of IFRS on final investors. This channel is associated with the impact of IFRS on the accounting method for evaluating financial products, that is, whether one uses MTM or MTC. We start to analyze the standard objections that are made to MTC financial products, such as low transparency and low liquidity. We observe that such objections need to be assessed in the context of an overall evaluation of financial products. Liquidity is priced in the market, and low liquidity products carry a premium. It remains to be seen whether the premium is large enough to compensate for the liquidity disadvantage. Heterogeneous sensitivities to the liquidity factor may imply different reactions to the market liquidity premium. Low transparency may also be associated with higher returns, not so much because of a market premium that needs to be paid for transparency risk, but because low transparency frequently is useful for the manager of the financial product. Managing a non-transparent financial product may allow an asset manager to maintain secrecy about the financial strategies. Of course, low transparency may be strategically used by the asset manager to expropriate investors, but this is part of the pathology of financial markets and is exactly the reason why low transparency is (rightly) criticized. Finally, we notice that low liquidity and low transparency are certainly negative elements for perfectly informed, rational investors. However, we claim that low liquidity and low transparency may carry some advantages for less than fully rational (we call them behavioral) investors. Behavioral investors may tend to overreact to news, misinterpret news, perform excessive trading and be overconfident. To such investors, high liquidity may be negative because of the expansion of financial freedom that is associated with it. Behavioral investors may find an advantage in tying their hands, and cost-based financial products may be an efficient way to do so. We briefly survey the large evidence that supports the idea that investors may often be moved by behavioral impulses.

After this introduction, the following section discusses the impact of the accounting regime on the value of insurance companies. The next section discusses the impact of the accounting regime on the characteristics of financial products, analyzing recent evidence on the behavior of investors and the various characteristics of MTM and MTC financial products. The final section concludes.

\section{The impact of the accounting regime on the value of insurance companies}

Since 2005 European insurance companies have to use IFRS. Importantly, European insurance companies have to comply with IFRS 4, by which the International Accounting Standard Board (IASB) has tried to force both convergence among different accounting standards applied through Europe and increased transparency of 
balance sheets. IFRS 4 largely uses market-based rules for determining such balance sheets.

However, the ultimate convergence target has not been completely achieved, as IASB has not been able to set general internationally accepted principles regarding technical reserves. Implementation of such principles has been postponed to a future "second part" of the IASB insurance project. It follows that the adoption of international accounting principles has induced some differences in the evaluation of assets and liabilities, as the latter keep being evaluated by means of the traditional local gap criteria. More specifically, while the assets side of the balance sheets moves from a prudential valuation criterion (varying from country to country) to a fair valuation criterion (based on market prices), the liabilities side associated with the sale of insurance contracts $^{2}$ is still valued at prudential terms (again varying from country to country).

For example, with reference to insurance products having the longest time horizon, and then to life insurance products, article 20 ("rules relating to technical provisions and their representation") of Directive 2002/83/EC of the European Parliament and of the Council of 5 November 2002 provides - among other things - that the amount of technical provisions shall be determined according to the following prudential principles:

- cash flows shall be estimated by a sufficiently prudent prospective actuarial valuation, that is, not a "best estimate" valuation, but one including an appropriate margin for adverse deviation of the relevant factors;

- the competent authority in the home Member State shall set a single maximum rate of interest for contracts containing an interest rate guarantee. It may differ according to the currency in which the contract is denominated, provided that it is not higher than 60 per cent of the rate paid on bond issued by the State in whose currency the contract is denominated. However, when the assets of the insurance are not valued at their purchase price, a Member State may stipulate that one or more maximum rates may be calculated taking into account the yield on the corresponding assets currently held, minus a prudential margin and, in particular for contracts with periodic premiums, furthermore taking into account the anticipated yield on future assets. The prudential margin and the maximum rate or rates of interest applied to the anticipated yield on future assets shall be fixed by the competent authority of the home Member State.

It follows that there is a potentially serious mismatch due to the need to evaluate assets by means of "best estimate" of cash flows and market interest rates, and liabilities by means of "prudent estimate" of cash flows and interest rates different from the market rates.

That means that, for the time being (and while waiting for the second phase of the IASB insurance project), the adoption of IFRS 4 may have an important impact on the valuation of insurance companies through, on the one hand, the greater volatility of earnings (as market-based earnings are likely to be more volatile than cost-based

\footnotetext{
${ }^{2}$ Insurance contracts are defined as contracts where "one party accepts significant insurance risk from another party by agreeing to compensate the policyholder if a specified uncertain future event adversely affects the policyholder".
} 
earnings) and, on the other hand, through the lower "quality" of the earnings as well (due to the inconsistency between assets and liabilities accounting principles).

So the main question is: will increasing earnings volatility and reducing earnings quality have an impact on market value of insurance companies? The answer is far from obvious and depends on various elements.

First, increasing earnings volatility may boost the risk premium required by investors and this may negatively affect prices. How can increasing earnings volatility affect risk premia? In an efficient market where investors hold diversified portfolios, increasing earnings volatility may be relevant through its effects on the sensitivity of stock returns to macroeconomic risk factors. The Arbitrage Pricing Theory suggests that the required return should depend on the sensitivity of the return of a company to risk factors and to the premium required by the market to hold portfolios closely correlated with such risk factors. A volatility increasing change in earnings may slightly change the sensitivity of the stock return to the risk factor, unless it is associated with a structural change. For example, increasing volatility resulting from a switch to a market-based accounting regime, magnifying the exposure of earnings to interest rate shocks, would correspond to an increase in the sensitivity to a fundamental risk factor like the interest rate. Required returns could well increase as a result, even for diversified portfolios.

Several empirical analyses also point to the existence of a systematic relation between idiosyncratic volatility and the value of the firm. ${ }^{3}$ Minton and Schrand ${ }^{4}$ find that cash flow volatility negatively affects investments and is associated with a higher cost of capital. Moreover, a low earnings volatility (a) increases analysts' attention because of its association with smaller forecasting errors, ${ }^{5}$ (b) increases demand on the part of institutional investors, ${ }^{6}$ and (c) decreases the cost of debt. ${ }^{7}$ Allayannis and Weston ${ }^{8}$ analyze a large sample of firms and find that a one standard deviation increase in cash flow volatility is associated with a reduction of the market-to-book ratio of between 6 and 21 per cent. The price earnings ratio itself seems to be associated with earnings volatility. ${ }^{9}$ There is moreover evidence of the negative impact on the value of the firms of announcements about changes in the accounting criteria, which may increase the volatility of earnings. ${ }^{10}$ These direct analyses suggest that a shift from cost- to market-based accounting could well have relevant impacts on the value of insurance companies.

Of course, insurance companies do not have to passively accept the increase in earnings volatility. They may hedge their risks. There is evidence suggesting that currency hedging increases the value of the firm. Allayannis and Weston ${ }^{11}$ study a

\footnotetext{
${ }^{3}$ See Goyal and Santa-Clara (2003); Malkiel and Xu (2002).

${ }^{4}$ Minton and Schrand (1999).

${ }^{5}$ Lang et al. (2003).

${ }^{6}$ Badrinath et al. (1989).

${ }^{7}$ Trueman and Titman (1988).

${ }^{8}$ Allayannis and Weston (2003).

${ }^{9}$ See Hunt et al. (2000); Thomas and Zhang (2002).

${ }^{10}$ See Collins et al. (1981).

11 Allayannis and Weston (2001).
} 
sample of 720 companies that are exposed to currency risk through sales from foreign operations and find a hedging premium (an increase in the market value) of about 5 per cent. Carter et al. ${ }^{12}$ estimate a 14 per cent premium for airlines hedging against fluctuations in the cost of fuel. However, Jin and Jorion ${ }^{13}$ study a large sample of U.S. oil and gas producers and find that hedging reduces the firm's stock price sensitivity to oil and gas prices but does not increase market value.

However, focusing on the accounting mismatch introduced by IASB principles adoption, insurers may hedge this risk:

a. by an investment strategy tracking the cost-based valuation of liabilities (for example by reducing the volatility of the assets portfolio by shorting its duration); b. by using the IASB-approved shadow accounting, consisting in the possibility of increasing or decreasing cost-valued liabilities consistently with the market appreciation or depreciation of the related market-valued assets.

In the first case (a), it seems clear that by hedging an accounting mismatch, insurers are introducing a real financial mismatch between assets and liabilities, reducing shortterm volatility and increasing long-term volatility. The rationale for this kind of hedging is that managers are heavily affected by short-term considerations. Graham et al. ${ }^{14}$ interview 401 U.S. managers and find that several companies are willing to destroy long-run value in order to reach quarterly targets. It follows that modifications of accounting criteria may trigger value-decreasing actions on the part of managers.

In the second case (b), the following theory has been subtly introduced: the value of liabilities generated by the sale of a long-term life insurance product containing an interest rate guarantee plus a potential upside is - with the exception of the case in which the assets covering the liabilities are not able to generate more income than the minimum guaranteed returns - always equal to the market value of the assets. It is clear that this theory does not take the effective characteristics of the life insurance products into consideration. For example, consider two simplified companies offering similar products with minimum guaranteed rate of return. Assume that both have the same assets (ten-year bonds with expected return equal to the minimum guaranteed rate of return on the related liabilities), but that the liabilities of the first (second) company will mature in 10 (1) years. The IASB-compliant financial statements of the two companies would appear to be substantially similar; however, it is obvious that the second company is more "mismatched" than the first and that its future earnings are more volatile. In other words, the adoption of the shadow accounting option reduces the earning quality.

There is evidence suggesting that investors take into account not only the level but also the quality of earnings. Chan et al. ${ }^{15}$ use the difference between the level of earnings and the level of cash flows as an indicator of earnings' quality and find that such a difference is negatively related to future returns. Companies with a large

\footnotetext{
${ }^{12}$ Carter et al. (2002).

13 Jin and Jorion (2006).

${ }^{14}$ Graham et al. (2004).

${ }^{15}$ Chan et al. (2006).
} 
difference between earnings and cash flow have had high rates of growth in the past but often produce low future returns. Leuz et al. ${ }^{16}$ show that earnings management takes place mostly in companies located in countries characterized by low investors' protection. Francis et al. ${ }^{17}$ show that companies with low earnings quality have a larger cost of debt (between 0.8 and 1.6 per cent), a larger cost of equity (between 1.5 and 3 per cent), a lower rating, a lower price earnings ratio, and higher beta.

\section{Investors and financial products}

\section{Cost-accounting and returns}

Many life insurance products are regarded by investors as less transparent and less liquid than financial products offered by banks and mutual funds. There are good reasons for such judgment: the financial performance for the investor of some products is usually valued at historical costs rather than at market prices. Moreover, some of them also involve limitations to trading, associated with the existence of fines that are to be paid if the product is sold before a certain future date and with the absence of a secondary market.

Such products are certainly less transparent than market-based products due to the fact that the financial return over a given holding period depends not only on market prices and dividends or coupons paid by the securities belonging in the portfolio but also on the smoothing decisions made by the insurance company. By managing the underlying portfolio, the insurance company may affect the book rate of return over a given period of time in order to smooth returns.

In simplified terms, in this kind of products the insurer sets out in advance the "appreciation period" (AP) of the product (usually 1 month or 1 year) to be used in calculating the performance for the policyholders, and at the end of each AP it acknowledges to investors the MTC rate of return of the assets. The difference between the MTM and the MTC rate of return of the assets will be:

- if positive, used to build up a buffer to be used in the future as follows;

- if negative, financed by the buffer or, if the buffer is zero, by insurer's capital.

If the algorithm underlying the MTC calculation is such that the MTC is the best estimate of the long-term expected rate of return of the assets, the long-term expected value of the buffer (and of the insurer's capital used to finance MTC) is equal to zero. In other words, in MTC products, the buffer and the insurer's capital are used to smooth the short-term volatility of the investor's investment.

As an example, Figure 1 reports a comparison between the dynamics of a six-year bond investment (with initial value equal to 100) in five different scenarios of returns between time 1 and time 6 . The gray lines show alternative scenarios that may take place when the product is marked to market, while the black line shows what happens

\footnotetext{
${ }^{16}$ Leuz et al. (2003).

${ }^{17}$ Francis et al. (2005).
} 


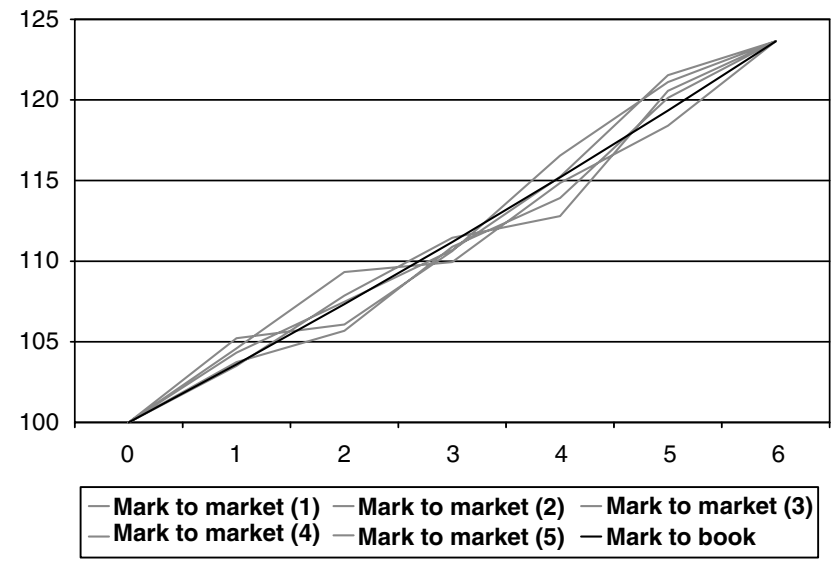

Figure 1. Comparison between the dynamics of a 6-year bond investment.

when the product is marked to cost according to the Italian Book Rate of return rules. In both cases the bond investment is represented by a coupon bond purchased at par and with a maturity of 6 years.

The figure shows that the final value is quite the same (there is only a marginal difference in the income from reinvested coupons), regardless of the accounting regime, but volatility is very different. In particular, volatility is zero when the product is marked to cost.

Low liquidity and low transparency are regarded as negative elements of financial products. This is certainly true if expected returns do not incorporate a correction for liquidity and transparency. But in efficient markets expected returns should increase by an amount which is large enough to compensate investors for liquidity and transparency risk. Indeed, the economic and financial literature has treated the relevance of liquidity and its impact on required returns. ${ }^{18}$ Pastor and Stambaugh ${ }^{19}$ estimate an aggregate liquidity factor and test whether such a factor is priced in the cross-section of expected returns. They find that the average return on stocks with high sensitivity to liquidity exceeds that for stocks with low sensitivities by 7.5 per cent annually after allowing for other standard risk factors like the market, size and value. Acharya and Pedersen ${ }^{20}$ find a smaller 4.6 per cent in a model which differs from that of Pastor and Stambaugh over the measurement of liquidity. In both cases, the liquidity premium is sizeable and economically significant, especially if one compares it to the overall market premium.

It is more difficult to find direct analysis about the existence of a transparency premium, even though one may notice that low transparency products like hedge funds and venture capital produce high average returns that may in part be regarded

\footnotetext{
18 See Amihud (2002) and Pastor and Stambaugh (2003).

${ }^{19}$ Pastor and Stambaugh, ibid.

${ }^{20}$ Acharya and Pedersen (2005).
} 
as a compensation for their opacity. Moreover, very often the high returns produced by hedge funds and venture capital are thought to be possible exactly because of lack of transparency, which may allow secrecy with respect to financial strategies chosen by the managers.

It is therefore conceivable that products offered by insurance companies compensate investors with a higher return as a compensation for lower liquidity and transparency and that these higher returns are possible exactly because low liquidity and transparency allow the manager of the product to adopt better financial strategies. Certainly one may wonder whether the pricing of the products is fair enough to pass the advantages of the various market premia to the final consumers. This, however, is a broader issue of competition in the insurance sector and in the financial market as a whole.

\section{The behavior of investors}

How might investors evaluate the characteristics of cost-based insurance products? We have previously mentioned elements which are usually regarded as negative traits, like low transparency and low liquidity. The point that we make in this section is that such traits, while clearly negative for a perfectly rational investor, may turn out to be beneficial to a less than fully rational investor.

There is a characteristic of insurance products which may benefit both fully rational and partially rational investors, and that is the low volatility. Risk aversion, the standard assumption to describe investors' behavior, implies aversion to volatility. Risk aversion is commonly assumed to describe both the behavior of expected utility maximizers and the behavior of non-expected utility maximizers. It follows that volatility smoothing is welfare enhancing if it does not negatively affect average returns.

However, there are other behavioral characteristics which have been empirically observed by researchers, some of which have been incorporated in recent models of rational financial choice. ${ }^{21}$ Empirical studies have pointed out to the existence of several behavioral biases, among which overconfidence and mental accounting, as well as several systematic mistakes like base rate neglect, sample size neglect, belief perseverance, anchoring, and availability biases.

Particularly relevant are the results of Barber and Odean, ${ }^{22}$ studying the relation between the frequency of trading and the average rate of return earned on the portfolio. The results very clearly show that investors obtain average returns which are negatively related with the frequency of trading. Gross return is more or less independent of trading, but net return is negatively associated with turnover. The natural interpretation is that the returns associated with the turnover are not able to make up for the costs of trading. The difference between net and gross returns is substantial: heavy traders show a return underperformance of about 6 per cent per annum.

Barber and Odean ${ }^{23}$ also show that the behavior of investors is not independent of the trading channel. Internet investors are more aggressive than standard investors,

\footnotetext{
${ }^{21}$ See Barberis and Thaler (2003) for a recent survey.

${ }^{22}$ Barber and Odean (2000).

${ }^{23}$ Barber and Odean (2002).
} 
perhaps because of the interaction between the information sets available online and the tendency to be overconfident. An overconfident individual is likely to look for all possible chances to act on excess confidence. The enormous increase in the information sets that can be found over the Internet therefore is likely to multiply possibilities for actions on the part of overconfident investors. This finding may also be associated with the fact that investors who frequently monitor the value of their portfolios may be more prone to trading and may also mistakenly hang on with losing stocks because of narrow framing and loss aversion.

In the light of this evidence, it is therefore interesting to evaluate the characteristics of insurance products. Some of their apparently negative elements may be regarded as positive given the financial behavior of many investors due to the discipline forced on them by restrictions to financial freedom. In particular:

- low liquidity may decrease the relevance of overconfidence; it prevents excessive trading, which may be very harmful to portfolio returns;

- low transparency may prevent excessive reactions in front of large market volatility; - a minimum guaranteed return may encourage some investors to buy risky assets which otherwise would be left out of the portfolio, in such a way increasing overall diversification.

Insurance products may therefore offer to behavioral investors the advantage of tying their hands. For these reasons we believe that insurance products may be complementary to those offered by banks and mutual funds and may be particularly important to some classes of investors. We certainly cannot forget that there are also negative elements, like the potential difficulty on the part of final investors to understand the true costs of insurance products as well as their structure, which often involves one or more implicit options. Under these conditions some investors may have imperfect understanding of the product and invest in them mainly because of a push on the part of sales. Supply-driven sales are indeed relevant in financial markets. Sirri and Tufano ${ }^{24}$ show that U.S. investors tend to buy mutual funds with a good result in the period preceding the purchase, but also mutual funds which are supported by a large marketing action.

\section{Utility evaluation of MTM and CB accounting}

Finally, to give analytical content to our hypotheses, we compare the total expected utility associated with a financial investment in a MTM product and the total expected utility associated with a financial investment in a cost-based (CB) financial product. More specifically, we consider a managed bond portfolio of the type usually found in insurance products. Let us denote with $x_{1}^{M}, x_{2}^{M} \ldots x_{T}^{M}$ the time series of MTM values of the managed portfolio over the life of the product, and with $x_{1}^{C}, x_{2}^{C} \ldots x_{T}^{C}$ the cost-based value of the same managed portfolio over the same horizon. Of course, the terminal values coincide, that is, $x_{T}^{C}=x_{T}^{M}$.

\footnotetext{
${ }^{24}$ Sirri and Tufano (1998).
} 
We consider two representative investors. One is characterized by a standard expected utility function of the log type defined over wealth at the end of the investment horizon $t$, as $p_{i} \log \left(W_{t, i}\right)$ where $W_{t, i}$ is the wealth at time $t$ in scenario $i$ and $p_{i}$ is the probability of scenario $i$. Assuming that wealth is totally invested in the financial product, expected utility associated with MTM accounting is $\sum_{i=1}^{n_{t}} p_{i} \log \left(x_{i, t}^{M}\right)$, where $n_{t}$ is the number of scenarios for period $t$. Expected utility associated with cost-based accounting is instead $\sum_{i=1}^{n_{t}} p_{i} \log \left(x_{i, t}^{C}\right)$.

The second investor is characterized by a myopic loss aversion utility function of the type used by Benartzi and Thaler: ${ }^{25}$

$$
\begin{gathered}
\pi_{i} v\left(\Delta W_{t, i}\right) \text { where } v\left(\Delta W_{t, i}\right)=\left\{\begin{array}{l}
\Delta W_{t, i}^{\alpha} \text { if } \Delta W_{t, i} 0 \\
-\lambda\left(-\Delta W_{t, i}\right)^{\alpha} \text { if } \Delta W_{t, i}<0
\end{array},\right. \\
\pi_{i}=w\left(P_{i}\right)-w\left(P_{i}^{*}\right),
\end{gathered}
$$

where $P_{i}$ is the probability of obtaining an outcome that is at least as good as $\Delta W_{i}$, and $P_{i}^{*}$ is the probability of obtaining an outcome that is strictly better than $\Delta W_{i}$ and where:

$$
w(x)=\frac{x^{\gamma}}{\left(x^{\gamma}+(1-x)^{\gamma}\right)^{1 / \gamma}}
$$

The various parameters considered by Benartzi and Thaler are $\alpha=0.88, \lambda=2.25$, $\gamma=0.65$. The myopic loss aversion function differs from the expected utility function also because of its considering the changes of wealth with respect to a given reference point. In our formulation the reference point is initial wealth and the investor therefore evaluates changes in wealth. Moreover, the investor uses two different functions to evaluate gains and losses and this creates an asymmetry between gains and losses. With the parameters suggested by Benartzi and Thaler, for example a loss of wealth equal to 5 is associated with a utility loss of 9.27 while a gain of wealth equal to 5 is associated with a utility gain of 4.12 , less than half the absolute value of the utility loss.

We are interested in comparing, from a welfare point of view, an MTM financial product with an MTC financial product. Of course, the comparison will remain within the same class of utility function, that is, we will compare an MTM product and the same product on the MTC version for an expected utility maximizer and we will repeat the exercise for an investor characterized by myopic loss aversion.

We will consider a 6-year investment horizon for both investors in the context of a scenario-based approach. For a given investment horizon $t$ we will generate $K=5,000$ simulations of returns. We will compute final wealth and change in wealth for each simulation and we will then evaluate expected utility on the basis of the simulations of final wealth (expected utility investor) and change in wealth (myopic investor). We will finally compare for each investor expected utility for the MTM and MTC versions of the insurance product, assuming that each investor only holds the specific financial

\footnotetext{
${ }^{25}$ Benartzi and Thaler (1995).
} 
The Geneva Papers on Risk and Insurance - Issues and Practice

174

Table 1 Mean and volatility of returns for a mark-to-market and mark-to-cost financial product

\begin{tabular}{ccccc}
\hline Period & $\begin{array}{c}\text { Mean return, } \\
\text { MTM }(\%)\end{array}$ & $\begin{array}{c}\text { Volatility, } \\
\text { MTM }(\%)\end{array}$ & $\begin{array}{c}\text { Mean return, } \\
\text { MTC }(\%)\end{array}$ & $\begin{array}{c}\text { Volatility, } \\
\text { MTC }(\%)\end{array}$ \\
\hline 1 & 3.23 & 6.96 & 3.75 & 0.00 \\
2 & 3.66 & 6.33 & 3.75 & 0.00 \\
3 & 3.63 & 5.26 & 3.75 & 0.00 \\
4 & 3.96 & 4.46 & 3.75 & 0.00 \\
5 & 4.25 & 3.84 & 3.75 & 0.00 \\
6 & 4.61 & 3.97 & 3.75 & 0.00 \\
\hline
\end{tabular}

product. The financial product consists of an investment in a bond with an original maturity of 6 years, decreasing over time. The positive slope term structure moves according to Cox-Ingersoll-Ross Model. ${ }^{26}$ In the MTM case there are no smoothing rules, so that in each simulation the return will be determined by extraction of a random variable. In the MTC case instead the return will be determined according to the Italian MTC rules.

Table 1 presents summary statistics for the mean and the volatility of the two cases. Since the bond is bought at par and its maturity is equal to the investment horizon, Italian MTC rules assure no volatility for the MTC portfolio.

In the MTM case, the average return increases over time while the volatility decreases. The increase in returns is due to the initial positive slope of the term structure, generating an average upward movement of the curve during the investment horizon pushing - during the first years - the bond price below par and then generating MTM returns lower than the YTM of the bond (3.75 per cent); during the last years, the upward depreciation effect is offset by the classic pull-to-par effect, pulling the price of the bond at par and then generating MTM returns higher than the YTM of the bond ( 3.75 per cent). The decrease in volatility is due to the decreasing maturity of the bond during the investment horizon.

Table 2 compares expected utility and loss aversion for the two financial products. The table clearly shows that the MTC version is superior to the MTM version from the point of view of expected utility, even though the differences are very small. The MTC version of the product increases welfare due to its reduction of return volatility and the frequency of loss scenarios. To understand the importance of the loss scenarios, it suffices to say that over the 6 years considered in the simulation the percentage of scenarios with a negative return is equal to 30 per cent in the first year, 26 per cent in the second year, 21 per cent in the third year, 14 per cent in the fourth year, 4 per cent in the fifth year and 0 per cent in the sixth year due to the pull-to-par effect. An MTM financial product would therefore expose the investor to several occasions of loss over the investment period.

The results are therefore revealing: they show that MTC financial products can be modestly beneficial for a rational expected utility maximizer who does not care

\footnotetext{
${ }^{26}$ Cox et al. (1985).
} 
Table 2 Expected $\log$ utility and expected loss aversion utility for mark-to-market and mark-to-book financial products

\begin{tabular}{lccc}
\hline $\begin{array}{l}\text { Expected utility, } \\
\text { MTM }\end{array}$ & $\begin{array}{c}\text { Expected utility, } \\
\text { MTC }\end{array}$ & $\begin{array}{c}\text { Myopic loss aversion, } \\
\text { MTM }\end{array}$ & $\begin{array}{c}\text { Myopic loss aversion, } \\
\text { MTC }\end{array}$ \\
\hline 4.6347 & 4.6420 & -0.0497 & 0.0540 \\
4.6687 & 4.6788 & -0.0197 & 0.0540 \\
4.7031 & 4.7156 & 0.0020 & 0.0540 \\
4.7410 & 4.7524 & 0.0321 & 0.0540 \\
4.7820 & 4.7892 & 0.0574 & 0.0540 \\
4.8263 & 4.8260 & 0.0701 & 0.0540 \\
\hline
\end{tabular}

particularly about losses, but can be highly beneficial to an investor characterized by loss aversion. The benefit of the cost-based products is associated with the strong reduction (elimination in our example) of the losses which can occur in the various scenarios. Only in the final part of the investment horizon, when losses are almost irrelevant, is the MTM product better than the MTC product. The behavioral aspects of investors, which have been briefly described above, induce us to claim that aversion to losses is standard among real-life investors. This implies that cost-based financial products may be highly relevant to most investors.

\section{Conclusions}

This paper has analyzed the relevance of cost-based accounting in financial markets. We have deliberately tried to focus on the drawbacks associated with a move from cost- to price-based accounting. The benefits of such a move, consisting of improved transparency and liquidity, are widely understood. Much less attention has been given to the potential hidden costs. We explore such hidden costs looking at both companies and investors as cost-based accounting is a far-reaching phenomenon, affecting the balance sheet of insurance companies, the products they offer and the investment opportunity set for users of such products.

From the point of view of insurance companies, we have highlighted the potential increase in earnings volatility associated with a switch from cost- to market-based accounting. Such increase in earnings volatility may have a material impact on the market valuation of insurance companies, also in view of the associated increase in the covariance of earnings with the movements of interest rates, a variable that many empirical studies identify as a non-diversifiable risk factor. A consequence of this increase is the associated penalty due to the resulting higher cost of capital. Finally, one should not forget that managers might react to increased earnings volatility by hedging, even though there are controversial results about the impact of systematic hedging on the market value of the firm.

From the point of view of the final investor, we noticed that cost-based accounting in financial products offered by insurance companies is often associated with negative characteristics such as low liquidity and low transparency. We have tried to reconsider this story from a different point of view, showing that in a world populated by 
investors behaving in less than fully rational way, cost-based financial products may be useful and welfare improving. Cost-based financial products may be associated with lower liquidity and very often with a smoothing of returns. Low liquidity may be negative for an expected utility investor, but positive for a less than rational investor. It is more difficult to buy and sell an illiquid asset, and such trade-decreasing properties may well cause higher returns if trading decreases rather than increases returns. Smoothing of returns may also be very positive, particularly for investors characterized by loss aversion. These investors suffer in those states of nature with negative returns and are happy to buy a product that offers higher returns in negative states of nature, compensated by lower returns in positive states.

Imposing on insurance companies to offer of MTM products may certainly be beneficial from the point of view of transparency, but would at the same time decrease the overall (across product) heterogeneity offered in financial markets. We suspect that such a loss would badly affect certain specific classes of investors, particularly those that behave in less than fully rational ways. Moreover, more transparent and liquid products may generate lower expected returns.

Our conclusion is that cost-accounting is a useful addition to financial markets. It may stabilize short-run financial results and may improve the situation of investors with short horizons and loss aversion. It is certainly true that cost-based financial products are not fully transparent and leave to the asset manager large discretion in the determination of short-run returns. We believe that cancellation of cost-based financial products is not the right reaction to these drawbacks. Rather, we believe that regulation and monitoring is the best answer, one that can reconcile the needs of ensuring investors' protection with the needs of free competition across financial intermediaries and the resulting rich supply of products that may be useful to investors characterized by varying time horizons, loss aversion and ultimately varying degrees of rationality.

\section{References}

Acharya, V.V. and Pedersen, L.H. (2005) 'Asset pricing with liquidity risk', Journal of Financial Economics 77: $375-410$.

Allayannis, G. and Weston, J. (2001) 'The use of foreign currency derivatives and firm market value', Review of Financial Studies 14: 243-276.

Allayannis, G. and Weston, J. (2003) Earnings volatility, cash flow volatility and firm value, Working paper, University of Virgina.

Amihud, Y. (2002) 'Illiquidity and stock returns: Cross-section and time-series effects', Journal of Financial Markets 5: 31-56.

Badrinath, S.G., Gay, G.D. and Kale, J.D. (1989) 'Patterns of institutional investment prudence and the 'managerial safety net' hypothesis', Journal of Risk and Insurance 56: 605-629.

Barber, B. and Odean, T. (2000) 'Trading is hazardous to your wealth: The common stock performance of individual investors', Journal of Finance 55: 773-806.

Barber, B. and Odean, T. (2002) 'Online investors: Do the slow die first?', Review of Financial Studies 15: 455-487.

Barberis, N. and Thaler, R. (2003) 'A survey of behavioural finance', in G.M. Constantinides, M. Harris and R. Stulz (eds) Handbook of the Economics of Finance, Amsterdam: Elsevier Science.

Benartzi, S. and Thaler, R.H. (1995) 'Myopic loss aversion and the equity premium puzzle', Quarterly Journal of Economics 110: 73-92. 
Booth, P., Chadburn, R., Cooper, D., Haberman, S. and James, D. (1999) Modern Actuarial Theory and Practice, New York: Chapman \& Hall/CRC.

Carter, D., Rogers, D. and Simkins, B. (2002) Does fuel hedging make economic sense? The case of U.S. airline industry, AFA 2004 San Diego Meetings, 16 September.

Chan, K., Chan, L.K.C., Jegadeesh, N. and Lakonishok, J. (2006) 'Earnings quality and stock returns', Journal of Business 3: 405-435.

Collins, D., Rozeff, M. and Dhaliwal, D. (1981) 'The economic determinants of the market reaction to proposed mandatory accounting changes in the oil and gas industry', Journal of Accounting and Economics 3: 37-71.

Cox, J.C., Ingersoll Jr., J.E. and Ross, S.A. (1985) 'A theory of the term structure of interest rates', Econometrica 53: 385-408.

Francis, J., LaFond, R., Olsson, P. and Schipper, K. (2005) 'The market pricing of earnings quality', Journal of Accounting and Economics 39: 295-327.

Goyal, A. and Santa-Clara, P. (2003) 'Idiosyncratic risk matters', Journal of Finance 58: 975-1007.

Graham, J.R., Harvey, C. and Rajgopal, S. (2004) The economic implications of corporate financial reporting, NBER Working paper 1050.

Hunt, A., Moyer, S. and Shevlin, T. (2000) Earnings volatility, earnings management and equity value, Working paper, University of Washington.

Jin, Y. and Jorion, P. (2006) 'Firm value and hedging: Evidence from U.S. oil and gas producers', Journal of Finance 61: 893-919.

Lang, M., Lins, K. and Miller, D. (2003) 'ADRs, analysts and accuracy: Does cross listing in the U.S. improve a firm's information environment and increase market value?' Journal of Accounting Research 41: $347-362$.

Leuz, C., Nanda, D. and Wysocki, P. (2003) 'Earnings management and investor protection: An international comparison', Journal of Financial Economics 69: 505-527.

Malkiel, B. and Xu, Y. (2002) Idiosyncratic risk and security returns, Working paper, University of Texas.

Minton, B. and Schrand, C. (1999) 'The impact of cash flow volatility on discretionary investment and the cost of debt and equity financing', Journal of Financial Economics 54: 423-460.

Pastor, L. and Stambaugh, K. (2003) 'Liquidity risk and expected stock returns', Journal of Political Economy 113: 642-685.

Sirri, E.R. and Tufano, P. (1998) 'Costly search and mutual fund flows', Journal of Finance 52: 1589-1622.

Thomas, J.K. and Zhang, H. (2002) Value-relevant properties of smoothed earnings, Working paper, Columbia University.

Trueman, B. and Titman, S. (1988) 'An explanation of accounting income smoothing', Journal of Accounting Research 26(supplement): S127-S139. 